\title{
Histological Investigation on the Herbicidal Effects of Alloxydim-sodium in Oat
}

\author{
Hisao Ishikawa, Susumu Okunuki, Takashi Kawana \\ and Yoshihiko Hirono \\ Nisso Institute for Life Science, Nippon Soda Co. Ltd., \\ 930 Oiso, Kanagawa 255, Japan \\ (Received April 12, 1980)
}

\begin{abstract}
The herbicidal action of alloxydim-sodium (ADS), sodium salt of 2-(1-allyloxyaminobutylidene)-5,5-dimethyl-4-methoxycarbonylcyclohexane-1,3-dione, on oat (Avena sativa) was investigated in post-emergence treatment. ADS applied to the foliage arrested the elongation of new leaves within two days and necrosis occurred in the meristematic region of the shoot within three days after treatment. At this time all leaves remained healthy in appearance. Subsequently, necrosis expanded to the base of the stem and finally to the entire plant. Histological investigations of the meristematic region of the shoots showed that the cell arrangement was abnormal, and nuclei appeared to be aggregated 12 hours after the treatment in the treated plants. These results suggested that ADS applied to the foliage primarily affected the apical meristems of shoots and disturbed the normal function in the meristems.
\end{abstract}

\section{INTRODUCTION}

A new herbicide, alloxydim-sodium (ADS), sodium salt of 2-(1-allyloxyaminobutylidene)5,5-dimethyl-4-methoxycarbonylcyclohexane1,3-dione, is a post-emergence substance to control gramineous weeds in soybean, sugar beet and other bloadleaf crops. ${ }^{1)}$ Its mode of action is not known.

The results previously obtained from greenhouse and field tests suggested that ADS seems to primarily affect the meristematic region. ${ }^{1,2)}$ The present experiments were initiated to further clarify this point using a microscopic technique.

\section{MATERIALS AND METHODS}

\section{Growth Response of Plants after Treatment}

Seeds of oat (Avena sativa, cultivar. Victory) were planted in pots $\left(100 \mathrm{~cm}^{2}\right)$ in a greenhouse $\left(15-28^{\circ} \mathrm{C}\right)$. When the plants were at 2.2-2.5 leaf-stage, an aqueous solution of ADS containing 1,000 ppm of Tween-20 was sprayed on the foliage at the rate of $0.4 \mathrm{~kg} / \mathrm{ha}$. Twenty uniform plants per pot were selected for the test. The lengths of leaf blades and leaf sheaths were measured at various times after the treatment (Fig. 1). At the same time longitudinal segments of the leaf sheaths were cut with a razor blade for photographing.

\section{Histological Investigation}

Oat plants at the two leaf-stage which had been grown in a greenhouse $\left(15-28^{\circ} \mathrm{C}\right)$ were sprayed with an aqueous solution of ADS containing $200 \mathrm{ppm}$ of Tween-20 at the rate of $0.4 \mathrm{~kg} / \mathrm{ha}$. Half a day and five days after the treatments, about $5 \mathrm{~mm}$ segments of the meristematic regions of the shoot were excised and placed in Carnoy solution, ethanol: chloroform: glacial acetic acid fixative $(6: 3$ : 1). After fixing for 12 hours the segments were embedded in paraffin utilizing standard techniques. Longitudinal sections of $7 \mu$ in thickness were cut with a rotary microtome and were stained by the Hydenhain and Eosin containing $4 \%$ of iron ammonium sulfate. $^{3)}$ 
Table 1 The effects of ADS on the elongation of leaf blades and leaf sheaths of oat.

\begin{tabular}{|c|c|c|c|c|c|c|}
\hline \multirow{3}{*}{$\begin{array}{l}\text { Application } \\
\text { rate }\end{array}$} & \multirow{3}{*}{ Organs } & \multicolumn{5}{|c|}{ Length $(\mathrm{cm})$, mean $\%$ of 0 day } \\
\hline & & \multicolumn{5}{|c|}{ Days after treatment } \\
\hline & & 0 & 1 & 2 & 5 & 10 \\
\hline \multirow{5}{*}{ Untreated } & Total length & $100(19.0)$ & 110.2 & 112.2 & 131.1 & 170.4 \\
\hline & First leaf & $100(8.1)$ & 100.0 & 100.0 & 100.0 & 100.0 \\
\hline & Second leaf & $100(15.8)$ & 101.3 & 101.3 & 101.3 & 101.3 \\
\hline & Third leaf & $100(4.1)$ & 122.0 & 219.5 & 480.5 & 561.0 \\
\hline & Leaf sheath & $100(4.0)$ & 137.5 & 155.0 & 165.0 & 207.5 \\
\hline \multirow{5}{*}{$\begin{array}{c}\text { ADS } \\
0.4 \mathrm{~kg} \text { ! ha }\end{array}$} & Total length & $100(20.1)$ & 114.4 & 114.4 & 119.4 & 119.4 \\
\hline & First leaf & $100(8.7)$ & 100.0 & 100.0 & 100.0 & 100.0 \\
\hline & Second leaf & $100(16.8)$ & 101.2 & 101.2 & 101.2 & 101.2 \\
\hline & Third leaf & $100(4.4)$ & 118.2 & 120.5 & 120.5 & 120.5 \\
\hline & Leaf sheath & $100(3.6)$ & 155.0 & 158.3 & 158.3 & 158.3 \\
\hline
\end{tabular}

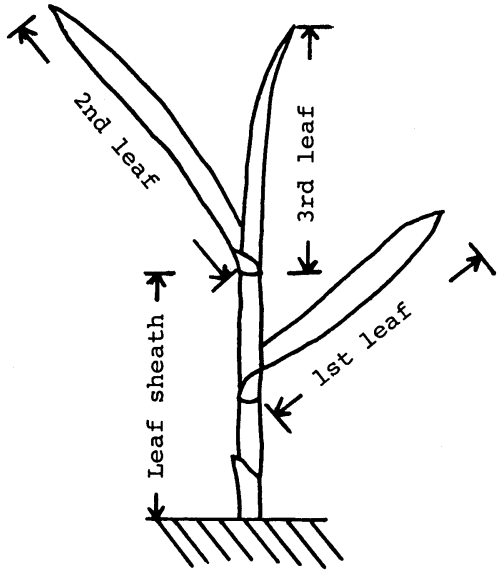

Fig. 1 Organ parts measured

\section{RESULTS}

1. Effects of ADS on Shoot Growth and in the Meristematic Tissues of Shoot

The lengths of the leaf blades and leaf sheaths after treatment were measured to determine the herbicidal action of ADS. Inhibition of the shoot growth began one day after treatment and the elongation of the shoots was completely suppressed within two days (Table 1). The elongation of the third leaf was most strongly inhibited by the treatment. This indicates that ADS particularly affects newly developing organs. No phytotoxicity was observed on the leaves at this time. The longitudinal sections of leaf sheaths showed no effects of ADS on the meristematic zone at their base two days after the treatment, but had slight necrotic symptoms on the zone three days after the treatment (Fig. 2). At this time all the leaves remained healthy in appearance, but then necrosis expanded to the whole zone and finally to the entire plant.

\section{Histological Investigation}

The experiments above-mentioned revealed that ADS applied to the foliage primarily arrested the elongation of new leaves and caused necrosis to the meristematic zone at the base of the leaf sheaths, followed by the necrotic death of the area. These results suggested that one of the sites affected by ADS is the apical meristem. Light-microscopic observations were conducted to investigate the effects of ADS on the meristematic area in more detail. The figures of the meristematic regions of shoot apex 12 hours after treatment are shown in Fig. 3-7. In untreated plants each cell divided in the regular direction and the distinction between tunica and corps was clear (Fig. 3). On the other hand, the cell arrangement was disordered and the borders of tunica and corps were not clear in the treated plants (Fig. 5). Furthermore, a number of dividing cells such as metaphase and anaphase cells were observed in untreated plants but not in treated ones (Figs. 4, 6). Nuclei of the cells in treated plants were deeply stained and appeared to be aggregated (Fig. 6). Tissues other than those of the meristematic region were normal in appear- 


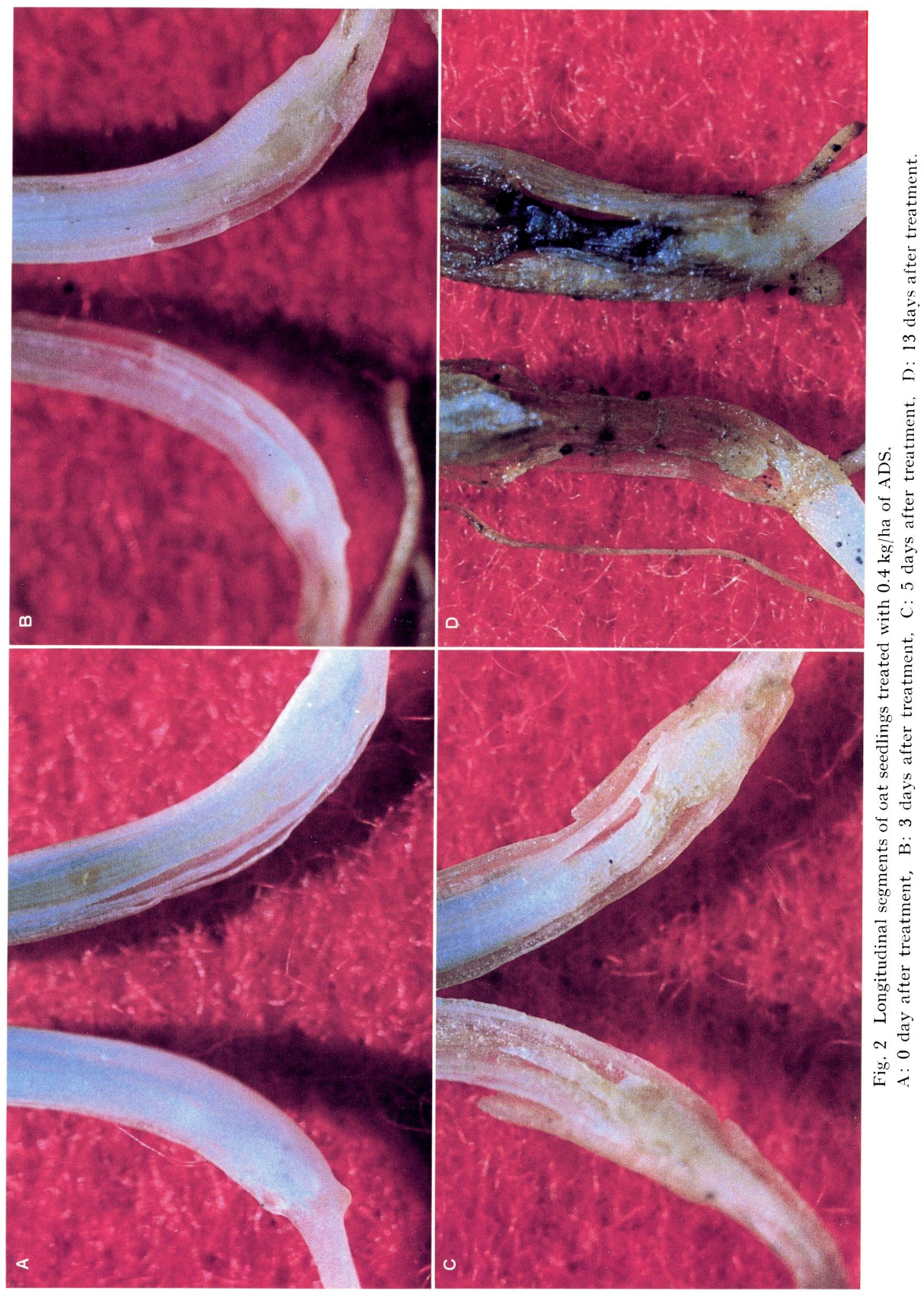




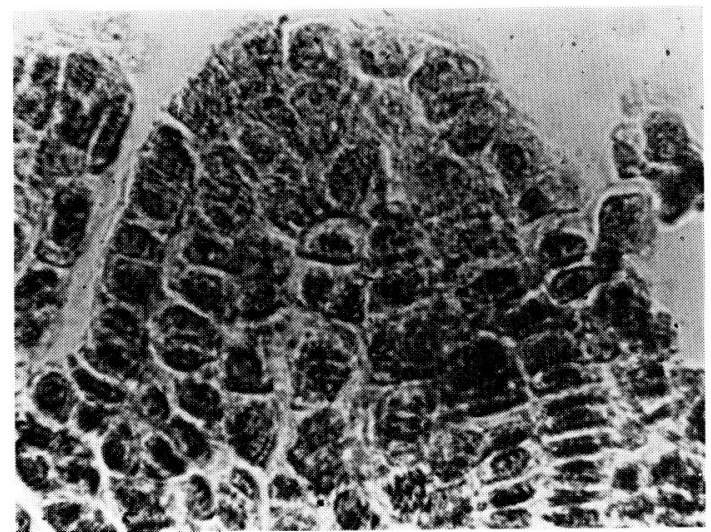

Fig. 3 Shoot apex of an oat secdling. Untreated. $(\times 420)$

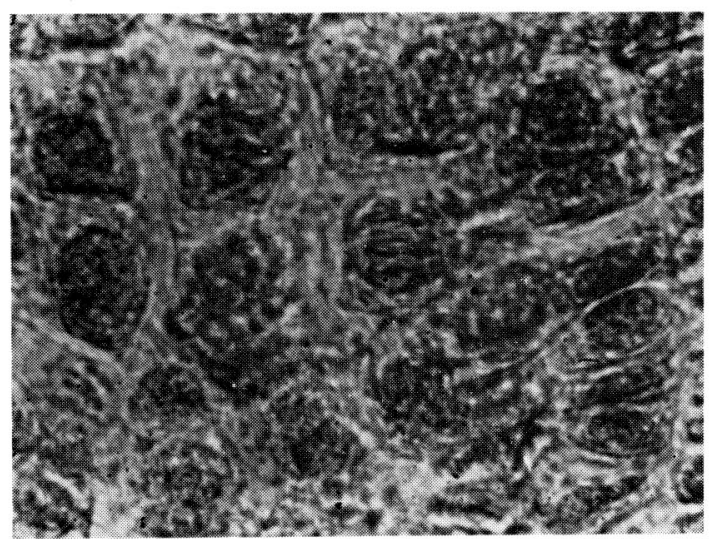

Fig. 4 Shoot apex of an oat secdling Untreated. $(\times 1,050)$

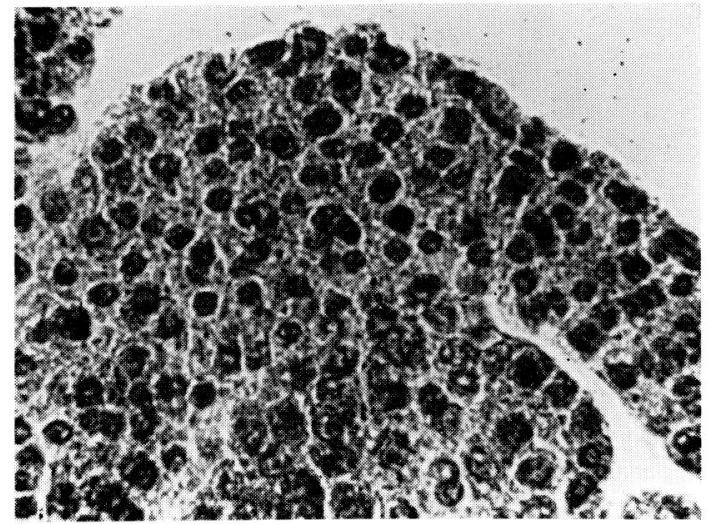

Fig. 5 Shoot apex of an oat seedling. Treated with $0.4 \mathrm{~kg} / \mathrm{ha}$ of $\mathrm{ADS}(12 \mathrm{hrs}$ after treatment). $(\times 420)$

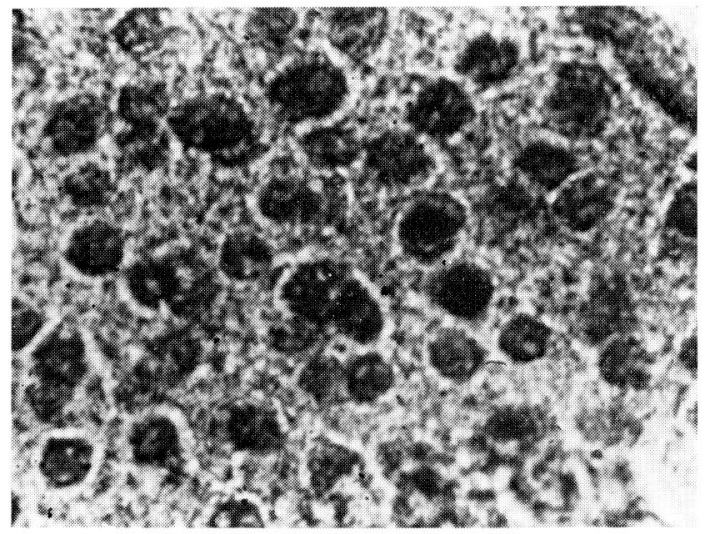

Fig. 6 Shoot apex of an oat seedling. Treated with $0.4 \mathrm{~kg} / \mathrm{ha}$ of $\mathrm{ADS}$ (12 hrs aiter treatment $).(\times 1,050)$

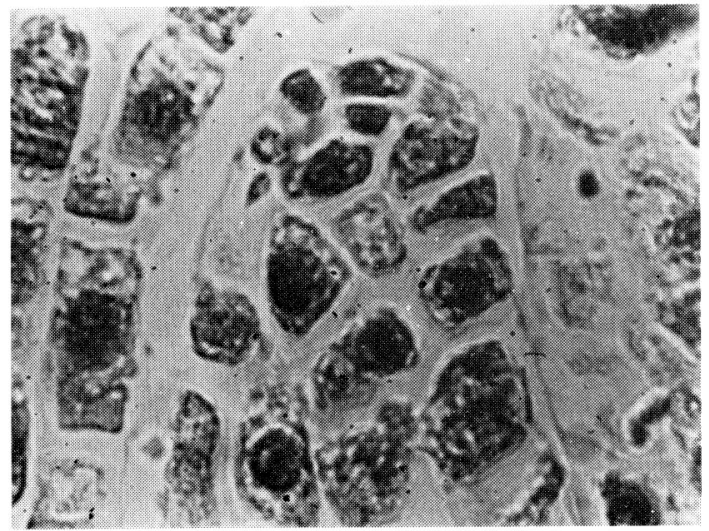

Fig. 7 Shoot apex of an oat seedling. Treated with $0.4 \mathrm{~kg} / \mathrm{ha}$ of $\mathrm{ADS}$ ( 5 (lays after treatment $).(\times 1,050)$

ance. The cell arrangement was more abnormal in the plant material examined five days after the treatment (Fig. 7).

\section{DISCUSSION}

As the foliar application tests suggested that ADS primarily affected the meristematic region of the shoot, further experiments were carried out to study the effects of ADS using a light-microscope. The experiments revealed that in treated plants nuclei appeared to be aggregated and the dividing figures such as metaphase and anaphase, which were frequently found in untreated meristems, were not observed. ADS seems to disrupt cell division 
in a different manner than herbicides such as IPC, 4) $\mathrm{S}-2847^{5)}$ and propamide ${ }^{6}$ ) which were reported to block mitosis at the metaphase stage.

The result that nuclei in treated tissues were deeply stained suggests that the meristematic region at 12 hours after treatment may be on the verge of death.

From these results it is believed that ADS applied to foliage primarily affects the meristems of shoots and disturbs the normal function of the tissues.

Phytotoxic symptoms appearing in plants after foliar application of ADS are an inhibition of growth, chlorosis in newly developing leaves and anthocyan formation in the old leaves. ${ }^{1,2)}$ The symptoms, growth inhibition and chlorosis, seem to be attributable to the damage to the meristem, and the anthocyan formation in the old leaves may be due to the accumulation of sucrose. These symptoms obviously differ from those of herbicides such as barban ${ }^{7)}$ and benthiocarb $^{8)}$ which were reported to inhibit protein synthesis. Furthermore, it was earlier reported that $\mathrm{ADS}$ did not inhibit protein synthesis. ${ }^{9)}$

Thus the inhibitory mechanism of cell division by ADS may be elucidated by factors other than the inhibition of protein synthesis and spindle apparatus.

\section{REFERENCE}

1) Y. Hirono, H. Ishikawa, T. Naohara \& $H$. Hosaka: Abstract of the 1st Annual Meeting of the Pest. Sci. Soc., Japan, Tokyo, No. 240, 1976

2) I. Iwataki \& Y. Hirono: "Advances in Pesticide Science," Pergamon Press, Oxford, p.

\section{5,1979}

3) M. Kijima: "Experimental Methods in Plant Morphology," Hirokawashoten, Tokyo, p. 83, 1962 (In Japanese)

4) W. B. Ennis: Am. J. Bot. 35, 15 (1948)

5) S. Sumida \& M. Ueda: Palnt Cell Physiol. 17, 1351 (1976)

6) W. C. Carlsom, E. M. Lingnowski \& H. J. Hopen: Weed Sci. 23, 155 (1975)

7) K. Kobayashi \& K. Ishizuka: Weed Sci. 22, 131 (1974)

8) I. Kimura, N. Ichizen \& S. Matsunaka: Weed Res. (Japan) 12, 54 (1971)

9) M. W. Bugg \& R. M. Haves: Proc. of the 31st Annual Meeting of the S. Weed Sci. Soc., USA, p. 245,1978

要約

\section{除草剤アロキシジムのエンバクに対する影響 の組織学的観察}

石川尚雄, 奥貫 進, 川名 貴, 広野好彦 栽培エンバクを用いて，アロキシジムの効果を検討し た. 供試戍の $0.4 \mathrm{~kg} / \mathrm{ha}$ 相当量散布されたエンバクは, 2 日以内に新葉伸長の完全停止がみられた. 処理後 5 日 目の葉鞘部について, 茎頂付近の縦断面を肉眼観察した 結果, 分裂組織部の褐变が認められた。しかしこのよう な状態での新葉, 展開葉との間には, 外見上の変化は認 められなかった，その後，このような褐変は，基部全体 から各部に拡大し，植物全体が枯死するに至った。この ようなことから，アロキシジムの効果について，茎頂部 分の光学的検鏡を行なった. アロキシジム散布 12 時間 後の茎頂分裂組織での細胞配列はきわめて不規則であ り，また高倍率での検鏡では，核はすべて凝集しており， 無処理区に見られたような分裂像は認められないことが わかった。フロキシジムはイネ科植物に卓勃を示すが， これはイネ科植物の茎頂部の分裂組織に作用し, 植物を 枯死に至らしめるものと推察された。 